\title{
Churnalism, Cultural (Inter)mediation and Sourcing in Cultural Journalism
}

Kristensen, Nete Nørgaard

Published in:

Journalism Studies

DOI:

10.1080/1461670X.2017.1330666

Publication date:

2018

Document version

Peer reviewed version

Citation for published version (APA):

Kristensen, N. N. (2018). Churnalism, Cultural (Inter)mediation and Sourcing in Cultural Journalism. Journalism Studies, 19(14), 2168-2186. https://doi.org/10.1080/1461670X.2017.1330666 
Post-print

Journalism Studies, published online 08 June 2017

https://doi.org/10.1080/1461670X.2017.1330666

(C) 2017 Informa UK Limited, trading as Taylor \& Francis Group

\title{
CHURNALISM, CULTURAL (INTER)MEDIATION AND SOURCING IN CULTURAL JOURNALISM
}

\author{
Nete Nørgaard Kristensen
}

Taking a point of departure in theories about cultural (inter)mediation, this article provides a theoretical framework for explaining the pervasion of churnalism within the specialised beat of cultural journalism. Compared to other types of journalists, cultural journalists are "journalists with a difference", since they are closely intertwined with sources, and public relations subsidies are "structurally embedded" in the beat's professional rationales. This has intensified with the professionalisation of the culture industries' media management during the past decades, prompting continuous critique of cultural journalists for not conforming to journalism's norms of sourcing. However, such critical claims are typically based on the conventional ideologies of Western journalism and often sidestep the distinct nature of this particular beat. These theoretical arguments are backed by a case study of the interplay of the publishing industry and the Danish press in relation to the publicising of the fourth Millennium book in 2015, a sequel to deceased author Stieg Larsson's successful trilogy from the mid-2000s. This case exemplifies cultural journalism's inclination towards "churnalism", and how churnalism may, in fact, comply with the beat's professional logics. However, it also shows that churnalism can spark critical meta-reflections among journalists on the interplay of the culture industries and the press.

KEYWORDS arts journalism; bestsellers; churnalism; cultural intermediaries; cultural intermediation; cultural journalism; Millennium books; meta-coverage

\section{Introduction}

This article analyses "churnalism" within the specialised beat of arts and cultural journalism. Drawing on Harcup's (2014) definition of churnalism as "A form of journalism that relies on recycling press releases and agency copy and which involves little or no independent reporting or attempt at verification", the article argues that churnalism has long been intrinsic to institutionalised news media's coverage of and critical debates about art and culture. This is because art critics and cultural journalists have been inclined to mediate between cultural producers and cultural consumers for decades (Bourdieu 1984; Janssen and Verboord 2015). Still, little scholarly attention has been devoted to how this specialised beat engages with 
churnalism, making it a topical issue for current research. This topicality is reinforced by the fact that the close intertwinement of the culture industries and the press often leads to cultural journalists being accused of running errands for the culture industries and not conforming to journalism's norms of sourcing (e.g. Olsen 2014). Since such critical claims are typically based on conventional ideologies of Western journalism (e.g. Deuze 2005), they often sidestep the distinct nature of this particular beat and the more nuanced types of interactions going on.

These theoretical arguments are tested and exemplified empirically by a case study of Danish newspapers' interplay with the publishing industry when the sequel to deceased author Stieg Larsson's bestselling trilogy, the fourth Millennium book, was publicised in 2015. The analysis is based on qualitative content analysis and interview data, and illustrates the very close ties between the culture industries and the press through numerous examples and types of churnalism. However, the analysis also shows that the Swedish book publisher Norstedts' meticulously orchestrated and controlled public relations (PR) campaign triggered significant reflection and meta-coverage among cultural journalists, adding a critical layer to the coverage and, more broadly, to the study of churnalism in cultural journalism.

The article consists of five sections. The first section argues in more depth for the need for journalism research to engage with cultural journalism when examining churnalism. Based on theories of cultural (inter)mediation, the second part provides a theoretical framework for understanding the key "mediation logic" in cultural journalism, which is the reason churnalism has long been an integral part of the beat's professional culture and interplay with sources. The third section gives a methodological outline of the case study, including brief perspectives on the Danish media systemic context and (bestseller) literature as case field. The fourth section presents the empirical analysis, and the final section considers the implications, suggested by the case, for the theoretical discussions of churnalism within cultural journalism. The article thus aims to provide a theoretical framework that may enable us to understand the penetration of churnalism within this specialised beat, and to provide empirical insight into churnalism's many forms and how it can spark more critical meta-reflectivity.

\section{Research Context:}

\section{Why Study Churnalism in Newspapers' Cultural Journalism?}

Journalism scholarship has pointed to the shared occupational "ideology" or "culture" of professional journalism, specifying how journalists should ideally practise their work in democratic societies (e.g. Deuze 2005; Hanitzsch 2007). At the same time, journalism is quite a diverse field, not only across countries (e.g. Hallin and Mancini 2004; Weaver and Willnat 2012) but also across sub-areas or beats (e.g. Turner and Orange 2013). Consequently, studies have emerged that look more closely at specialised but also hybrid types of journalism, such as arts journalism (Harries and Wahl-Jorgensen 2007; Janssen, Kuipers, and Verboord 2008; Sarrimo 2016; Verboord and Janssen 2015), cultural journalism (Golin and Cardoso 2009; Jaakkola 2015; Kristensen and From 2015a), lifestyle journalism (Hanusch 2012; Kristensen and From 2012) and celebrity journalism (Dubied and Hanitzsch 2014; Van den Bulck, Paulussen, and Bels 2016). This newer research agenda that studies these topics as specialised types of journalism with their own norms and routines can be seen as a counter-trend to the 
inclination towards studying "the most sacred part of journalism": political journalism (Neveu 2002, 23).

Within the areas of arts and cultural journalism, research has shown that cultural journalists across cultural sub-fields and within particular cultural fields, e.g. literature or music, have quite different conceptions of societal obligations and professional values compared to other types of journalists. This influences their daily practices, for example, when interacting with sources. Studying music journalists, Forde $(2003,113)$, for example, uses the notion of such journalists being "journalists with a difference"1 because of their qualifications, entry and career paths, and their main task of being critics rather than reporters. Harries and WahlJorgensen (2007) use the term "arts exceptionalism" about arts and cultural journalists more broadly, pointing to their self-understanding of being better qualified than news reporters. This exceptionalism is linked to their perceived need for aesthetic specialisation, to the fact that they find objectivity less relevant or important in their work, and, finally, to them taking "on a crusading role, describing their work as infused by a passion which is otherwise frowned upon within journalism cultures". Similarly, Hellman and Jaakkola $(2012,785)$ use the term "aesthetic paradigm" to explain that the values of art and culture drive cultural journalists' professional practices as "a representative of the artistic field in the newspaper rather than a representative of the journalistic field in the arts".

These studies point to the importance of looking into the specialised nature of particular journalistic beats, for example, when trying to grasp a phenomenon such as churnalism. Therefore, this article focuses on churnalism in cultural journalism, which is the term used in a lot of European and especially Nordic research (for overviews, see Kristensen and From 2015a; Jaakkola 2015); the term comprises news stories, reviews and commentaries on art and culture. ${ }^{2}$ The article focuses especially on churnalism in professionally produced cultural journalism in institutionalised newspapers. Although the increasingly fragmented and digitalised media landscape has provided numerous occasions for communication and evaluation of art and culture in less or non-institutionalised media settings (e.g. on blogs, review websites and fan sites), institutionalised news media still play an important role in the cultural public sphere (Gripsrud 2009). Not only does cultural journalism have a long tradition in newspapers, but newspapers also still serve as an important interface between cultural producers and broader audiences, as a forum for shared experiences by bringing public awareness to cultural phenomena, and as an arena for cultural producers and artists to gain cultural legitimacy (Hjarvard 2013; Knapskog and Larsen 2008). This is not least the case in a Nordic context, where culture is key to professional journalists' "welfare state of mind" (Ahva et al. 2016; see also Syvertsen et al. 2014).

\section{Theoretical Framework:}

\section{Cultural Journalists as "Mediators" Intertwined with Sources}

Theoretically we can try to understand the particular ideology of cultural journalism by means of Bourdieu's (1984) concept of the "cultural intermediary" and, more recently, Janssen and Verboord's (2015) notion of "cultural mediators"; that is, theories that may also help explain why churnalism is pronounced in cultural journalism and perhaps even complies with the 
professional norms and practices of the beat, for example, in the interplay with sources.

When Bourdieu introduced the term "cultural intermediary" in the late 1960s, he referred to, among others, "the producers of cultural programmes on TV and radio or the critics of 'quality' newspapers and magazines and all the writer-journalists and journalist-writers" (Bourdieu 1984, 325). Thus, cultural journalists and critics were among the then emerging occupations that acquired an important cultural and market role by mediating between cultural producers and consumers and by ascribing value to cultural products as part of this mediation process, potentially influencing cultural publics' and consumers' perceptions. ${ }^{3}$ More recently, Janssen and Verboord (2015) have outlined seven different roles or types of cultural mediation work that "cultural mediators" - the term they use - may perform in the life cycles of cultural products. Four of these are of particular importance in the context of churnalism and sourcing in cultural journalism.

The first role is gatekeeping, which refers to cultural mediators, for example, cultural journalists, selecting and directing attention towards some cultural products and not others, thus echoing scholarship on gatekeeping in journalism more generally (e.g. Shoemaker, Vos, and Reese 2009). This gatekeeping role is especially important at a time of cultural over-supply, when cultural editors and journalists have to select crudely from the increasingly vast stream of press releases for cultural products and events flowing to their desk (Kristensen and From 2015b; Thompson 2007). While this gatekeeping may thus be influenced by various types of information subsides (Gandy 1982), it may itself influence which cultural products gain broader attention in the cultural public sphere and among cultural consumers - and which are ignored or only picked up by niche publics.

The second role is connecting/networking, which refers to the cultural field being greatly dependent on networking. While Janssen and Verboord (2015) use the concept about various types of cultural agents - literary agents, curators, art dealers - who match artists and industrial partners (publishers, galleries, etc.), in cultural journalism, it refers to the intertwinement of artists, cultural producers and journalists. They often mingle in the same circles through friendshiplike relations or close collegial collaborations, and cultural journalists often share their sources' aims, interests and passions for art and culture rather than playing the traditional adversary role (Forde 2003; Kristensen 2003). Such a situation is especially pronounced in a geographical context like the Danish with a small-scale cultural scene and press (see also Jackson and Moloney 2016).

The third role, selling/marketing, refers to, for example, cultural journalists providing free publicity when they preannounce, cover or review cultural products, artists or events, even though such promotion may not be the primary goal of these journalistic texts. Nonetheless preand reviewing have been essential genres to cultural journalism since the early press (Davis 2013; Jaakkola 2015; Kristensen 2010) and exemplify how churnalism has a long tradition within this specialised beat. This is closely linked to cultural journalism being heavily dependent on the publication, release or opening dates of the cultural field (Scott 1999), making the present "a determining value for selection" (Golin and Cardoso 2009, 78). Some even argue that the culture industries set the agenda for the cultural beat since "temporal 
proximity is a structural axis for the coverage constituted by the routine of releases and the circulation of cultural products" (81). The research literature uses terms such as "cheerleader", "annex of a label's publicity department" (Klein 2005, 13) and "cultural patriots" (Hovden and Knapskog 2015, 791) to describe cultural journalists' reliance on PR material, even though the dependence is reciprocal, since the culture industries also need the news media to publicise their products (Davis 2013).

The final role is evaluating, classifying and meaning making, which refers to cultural mediators, especially critics, describing, interpreting and evaluating cultural goods, by means of the beat's key genre: the review (e.g. Shrum 1991). Although the scholarly literature points to mixed findings in terms of how reviews influence audiences' cultural consumption, it has shown that quality debates and criticism in cultural journalism have contributed to legitimising particularly popular culture expressions such as movies, television drama and popular music in the cultural hierarchy (e.g. Baumann 2001; Koreman 2014; Rixon 2011; Schmutz et al. 2010).

Gatekeeping and networking also apply to other types of journalism, since all journalists serve as gatekeepers to their sources' access to the news arena; a solid source network is a prerequisite for all journalists in their daily work; and interdependencies may arise between journalists and sources within any beat (e.g. Shoemaker, Vos, and Reese 2009). However, these logics of mediation are in cultural journalism closely linked to the logics of selling/marketing and cultural valorisation/classification, which are, as indicated, distinct to this beat. The shared loyalty and passion for art and culture, the often personal affiliations of journalists, publicists and artists, as well as the structural determinants of the culture industries' releases seem to make PR subsidies "structurally embedded" (Strahan 2011, 128) in the beat's professional rationales. ${ }^{4}$ This fact makes sources from the cultural field key players in the reporting, while typical sources in journalism, such as politicians or experts, play a less prominent role (Kristensen 2016). Furthermore, listings, capsule reviews and scaled ratings are common conventions in cultural journalism, that is, conventions that aim to guide media audiences' cultural consumption (Blank 2007; Szántó, Levy, and Tyndall 2004) but which also serve as PR or marketing devices for the culture industries. Cultural journalists admit to playing such a dual role-serving both artists/ the culture industries and the cultural public/consumers (e.g. Kristensen 2003). These symbiotic relations with sources distance the beat from traditional professional norms such as objectivity and power or market autonomy; or rather, the selling and valorisation logics make such values less important or applicable. While this may explain why churnalism has for long been an integral part of cultural journalism, it has prompted continuous critique of cultural journalists for being subservient to sources and for ignoring journalism's norm of independence, e.g. from the culture industries (Jaakkola 2015; Olsen 2014). However, these critical claims are, firstly, based on the conventional ideologies of journalism (e.g. Deuze 2005; Hanitzsch 2007) and therefore, to some extent, sidestep cultural journalism's mediator logics. Secondly, little research has been devoted to scrutinising how the mediator logics influence journalistic text production in empirical practice, and thus how churnalism manifests itself. The following analysis aims to fill part of this empirical void.

\section{Empirical Context and Research Design}


The following subsections introduce the Danish media systemic context, and how it implicitly facilitates the mediator logics of cultural journalism; (bestseller) literature as a particularly interesting case field when studying churnalism in cultural journalism; and the design behind the Millennium case study.

\section{News Media and Cultural Journalism in Denmark}

The Danish media system is located within the Democratic Corporatist Model (Hallin and Mancini 2004) or the Nordic Media Welfare Model (Syvertsen et al. 2014), characterised by strong journalistic professionalism and autonomy. Being partly publicly funded, the media are also subject to a certain degree of state intervention to ensure a varied press with high circulation and a diverse media landscape, grounded in the idea of public service. This public service approach and the subsidy system prioritise art and culture. The Law on Media Subsidy (No. 1604, revised in 2013), for example, stresses that attention has to be given to cultural themes for a print or internet-based news medium to qualify for media subsidy. Also the Radio and Television Broadcasting Act (No. 255, revised in 2014) stipulates that public service media must give coverage to (Danish) culture and reflect the range of art and culture produced as well as the diversity of cultural interests in Danish society.

Like in most other Western countries, the introduction of online-based news services has changed the news ecology and economy in Denmark. Printed newspapers have experienced a decline in readers, while an increasing portion of the population of 5.6 million people access news online. Nevertheless, national television and newspapers (print/ online) continue to be important news sources for most Danes (e.g. Newman, Levy, and Nielsen 2015). This confirms the importance of investigating the role of churnalism in cultural journalism in institutionalised newspapers. Of particular importance is the fact that public service obligations to art and culture are still intrinsic to most Danish journalists, whether working for (mainly) publicly funded or commercially based media (Ahva et al. 2016). Thus, the subsidy regulations as well as the professional, journalistic culture in Denmark implicitly support the cultural (inter)mediary logics of cultural journalism.

\section{Literature in Cultural Journalism}

Literature is a relevant case field when studying churnalism in (Danish) cultural journalism for at least two reasons. Firstly, literature continues to have a significant place on the news agenda, despite an increasingly inclusive press coverage of culture during the twentieth century. This is the case internationally (e.g. Jaakkola 2015; Janssen, Kuipers, and Verboord 2008; Knapskog and Larsen 2008; Szántó, Levy, and Tyndall 2004) as well as in Denmark, where 1 in 10 cultural newspaper stories concerns books (Kristensen 2010,2016). This priority reflects the Danish public's huge interest in and increasing consumption of literature (Danish Agency of Culture 2016), making it an important field for cultural journalists to cover for both publicist and commercial reasons. Readers of literature still look to institutionalised news media for guidance in an increasingly multifarious book market (From 2010; Hjarvard 2016; Verboord 2010), which may explain the above-mentioned service aspect of cultural journalism, exemplified by bestseller lists and ratings. 
Secondly, an increasing number of books are published in print and digitally in Denmark (Danish Agency of Culture 2016) as well as internationally (Thompson 2010). This means that book production and distribution, especially of (potential) bestsellers, is an increasingly precarious business, characterised by commercial high risk and also potentially high gain - or loss. One way of minimising such risk is by meticulously planning and strictly controlling marketing and PR efforts (Davis 2013), since the typically very short profit windows intensify the need for maximum public attention prior to release dates. Helgason, Kärrholm, and Steiner argue that the breakthrough of a single bestselling title is often dependent on marketing strategies coupled with the word-of-mouth effect of enthusiastic readers. Being a phenomenon placed somewhere in between the power spheres of producers and consumers is one of the things that makes the bestsellers particularly interesting. (Helgason, Kärrholm, and Steiner 2014, 8)

As suggested by the theories of cultural intermediation, cultural journalists may play such a mediating part, resulting in a line of PR genres emerging to hype cultural product releases like bestsellers and turn them into major media or news events. This is done to ensure that cultural journalists as gatekeepers provide publicity and ascribe cultural value, and it has increased the push for churnalism in the literary field.

\section{The Fourth Millennium Book Case Study}

In December 2013, the Swedish publishing house Norstedts made it public that Swedish journalist and author David Lagercrantz was to continue the work of one of the previous decade's most successful crime fiction writers, Stieg Larsson, who died in 2004. Lagercrantz was commissioned to write the fourth Millennium book, The Girl in the Spider's Web, following up on Larsson's successful trilogy, published from 2005 to 2007. The fourth Millennium book was published worldwide at midnight between 26 and 27 August 2015 in more than 20 countries. This case is extreme in view of the previous trilogy's huge commercial as well as critical success (Helgason, Kärrholm, and Steiner 2014), the controversial nature of the production of the fourth book and its longitudinal promotion. It is thus far from archetypal, perhaps even an outlier, of the interplay between cultural producers and the press, or of churnalism in cultural journalism more generally. Still, it explicitly exemplifies the complex mediator logics of the cultural press and their implications for churnalism within this specialised beat.

The following analysis is based on a qualitative content analysis (Schreier 2012) and a qualitative interview. Articles from the print edition of nine Danish newspapers were included, representing various types of newspapers with the largest circulation within their category: two tabloids, three national newspapers, two niche newspapers and two regional newspapers. ${ }^{5}$ The systematic sampling was conducted by means of Informedia, an online provider of digital access to most Danish newspapers in print and online. To encompass the entire cultural news coverage of the book - from the announcement of Lagercrantz being commissioned to the book's international publishing and its reception by critics and readers - the sample period was 1 December 2013 to 1 January 2016. "David Lagercrantz" was used as search word, providing a sample of 218 articles. Excluding bestseller lists (91) and articles not concerning the Millennium book (36) reduced the sample to 91 articles, which have been analysed by coding 
for the topic of the stories, the sources used and the critical discourses applied. ${ }^{6}$ Though the sample has been coded systematically, the analysis mainly presents qualitative findings in view of the sample size. Furthermore, a qualitative interview was conducted with CEO Ilse Nørr from the Danish publishing house, Modtryk, which published the Millennium book in Denmark. Modtryk had also published the previous Millennium trilogy as well as thrillers by other successful Nordic crime authors, such as Norwegian Jo Nesbø and Swedish Jan Guillou. The interview was conducted on 30 August 2016 at the facilities of Modtryk and transcribed word-for-word by a research assistant. While the interview sheds light on the publishing industry's push for churnalism in the Millennium case, the qualitative content analysis displays how this churnalism manifested itself in the cultural reporting. Combining the two types of qualitative data aims to increase the validity of the overall conclusions.

\section{Analysis: Push for Churnalism and Critical Meta-coverage}

The following analysis presents the publisher's attempts at media management, and how the news media quite extensively picked up on this strategy and provided churnalism. However, it also shows how this interplay of the culture industries and the press spurred meta-coverage and influenced both news articles and reviews.

\section{The Publisher's Unprecedentedly Controlled PR Strategy}

The interview with the Danish publisher, Modtryk, reflects a meticulously orchestrated PR strategy on the part of the Swedish publisher, Norstedts. While Modtryk had relatively free hands in terms of the marketing (e.g. in which types of media the book should be advertised), it had limited PR manoeuvring space when it came to the national press, since it had to abide by strict clauses of silence specified by Norstedts. The Swedish publisher circulated narrowly but strategically planted bits of information for a period of two years: who was to write the book, the publication date, the look of the national book covers, etc. Ilse Nørr explains, "The marketing we planned ourselves, but as for the PR ... we were told when to make [something] public ... we were not allowed to publicise anything that the Swedes had not publicised or would publicise the same day". According to the Danish publisher, these conditions also applied to other countries where the book was published, indicating that the Danish context was not exceptional.

Author David Lagercrantz was also staged as an important but somewhat hard-to- gain-accessto part of the book release, since the Swedish publisher controlled when the press could interview him, what they could interview him about and when interviews could be published. The Danish publisher explains:

We were allowed to send some journalists to Sweden to talk to Lagercrantz in June [2015 for a press junket], and they had to sign an agreement that the interview they made would not be published before August 27. They signed and in fact also kept to this agreement ... and then we were allowed to send some journalists to Stockholm for August 26 and 27 when a press conference was held ... and 15 minutes were allocated to some journalists. (Ilse Nørr, CEO, Modtryk)

Although the elite-niche newspaper Information did in fact succeed in publishing an interview 
with Lagercrantz before the international book launch, also this interview (published March 7, 2015) was subject to restrictions, as demonstrated in this quote from the article, "We are to talk about his new book, but it is going to be an odd interview, because I have not read the book, and he is not allowed to talk about it." In August 2015, Norstedts also released a diary that Lagercrantz had kept while writing the book. However, the press did not get a copy of the Millennium book until the international release day, which was quite unique for such a huge Nordic book publication, because it meant that the critics could not review it on its publication day. ${ }^{7}$

The publisher's strategy thus became agenda setting for the press coverage of the book, but this control and the restrictions did not go unnoticed in this coverage, as the following parts of the analysis show.

\section{The Press' Preannouncements of the Book: Various Examples and Types of Churnalism}

The publishing of the fourth Millennium book represented an important cultural news story to the Danish press across all types of newspapers, since it was covered during the entire timespan from the end of 2013 through 2015, but, not surprisingly, most intensively just prior to and after the release date of 27 August 2015 (see Figure 1).

\section{FIGURE 1}

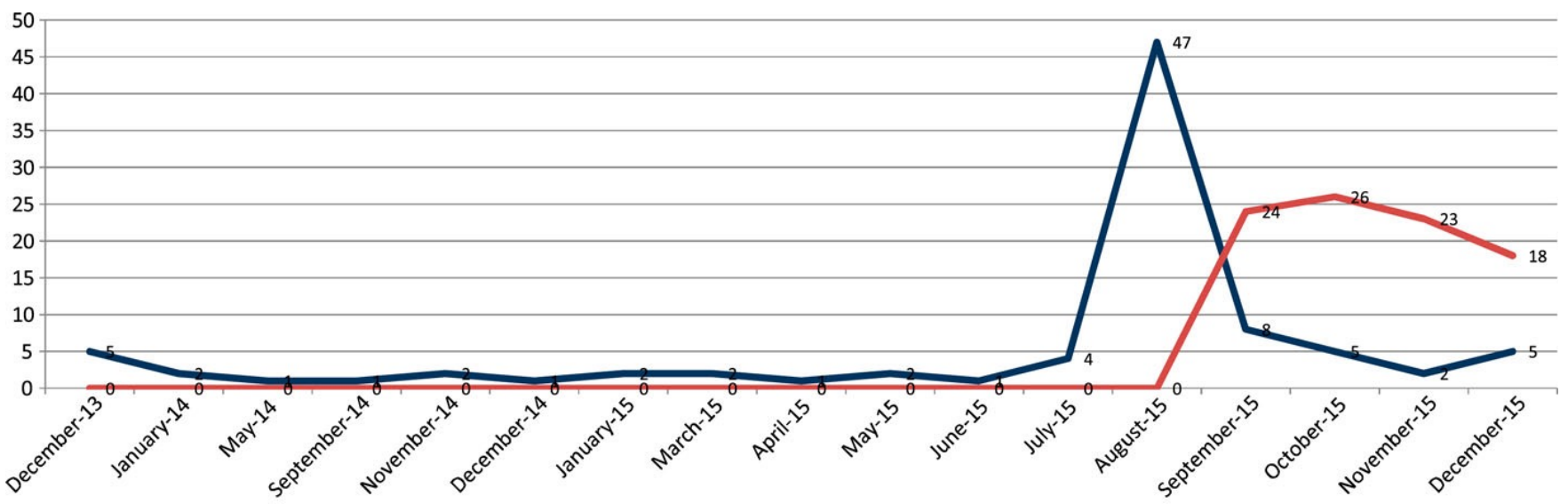

Number of articles $(\mathrm{N}=91)$ and bestseller $\overline{\text { lists }}(\mathrm{Article}=\overline{\mathrm{Nes}}$

The coverage includes numerous examples of churnalism: 18 December 2013, several newspapers, for example, announced, under quite similar headlines, that there would be a fourth book and that David Lagercrantz would write it: "Publisher wants to revive Stieg Larsson" (same headline in BT and Berlingske) and "The Fourth in the Trilogy" (Politiken); similar headlines surfaced by the end of January 2015, when the Swedish title of the book, Det som inte dödar oss, was released: "New Millennium Coming Up" (Politiken, January 28, 2015) and "Lisbeth Salander Returns" (Jyllands-Posten, January 31, 2015); by late Spring 2015, newspapers covered what little information was released about the book's plot; similar stories appeared by the end of July 2015 under headlines such as “"New' Stieg Larsson is About 
Artificial Intelligence" (Politiken, April 1, 2015), "Fourth Book in the Millennium Series to be Published in August. Read about the Plot Here" (BT, May 28, 2015), "More Details About New Stieg Larsson Book" (Jyllands-Posten, July 25, 2015) and "Salander Wants to Hack NSA" (Politiken, July 28, 2015). Several of these previewing articles include quotes from Lagercrantz, typically cited from Swedish news media, but they also make reference to the Swedish or Danish publisher. Other articles informed about the number of copies of the book's first edition, and, after its publication, provided short updates on its sizeable sales numbers, for example: "New Stieg Larsson Thriller Will Have a 2.7-mil. Copy First Edition" (Berlingske, August 25, 2015), "The New Millennium Book Sells Well” (Berlingske, September 13, 2015), "The Readers Still Crazy About Lisbeth" (Politiken, September 14, 2015) and "The Fourth Book About Lisbeth Salander is a Big Hit" (Jyllands-Posten, October 5, 2015). This resembles "horse-race journalism", a term typically associated with press coverage of political elections (Littlewood 1998), but Thompson $(2007,112)$ has also used it about blockbuster box office expectations and opening weekend results. The Millennium case shows that it may also be applied to cultural reporting on the commercial expectations, success criteria, number of copies, etc., of bestseller literature. Even though these articles may have been subject to some editorial versioning, rather than pure recycling of press releases, their publication dates, similar headlines and related content suggest that they are based on the publisher's information subsidies (Gandy 1982; Harcup 2014). This is confirmed by the qualitative interview with the Danish publisher, who states, "Every- thing we were allowed to publicise was received [by the press]".

Two newspapers published extracts of the book's first chapter prior to the international release which constitutes a more extreme example of PR orchestration. On August 23, 2015, the national newspaper Berlingske writes, "Exclusively for Denmark, Berlingske has been allowed to publish a chapter from 'The Girl in the Spider's Web"', while the tabloid Ekstra Bladet, under the framework of "Exclusive Sneak Peak", August 27, 2015, writes "Read the first chapter of the book here". This publishing was thus framed as a privilege and exclusive service to the newspapers' readers, although the exclusivity was staged by the Swedish pub- lisher, allowing only selected newspapers such a sneak peak.

A final example of churnalism-like content is bestseller lists, which serve the commercial functions of identifying, marketing and framing books as bestsellers, and being a selection tool for readers (Helgason, Kärrholm, and Steiner 2014, 17). Between September and December 2015, 91 bestseller lists were published, typically listing the Millennium book among the top three, which demonstrates that the book quickly became a commercial success.

Thus, the Swedish publisher was successful in promoting the book as newsworthy, resulting in the cultural desks covering it quite extensively, based on the scarce information circulated by the publisher. In this way, the press played a significant role in building expectations about the commercial as well as literary qualities of the book. These expectations culminated at the international release in view of the reviewers' verdicts (see below), and in the following weeks in view of the book's presence on the bestseller lists. As indicated by Figure 1, the book's news value waned quite quickly once this suspense was released, whereas its success on the bestseller lists lasted for months. 
While it may be difficult for publishers to get press coverage of certain books and pass the cultural journalists' gate in view of the increasingly competitive book market, the opposite was the case for the fourth Millennium release. The analysis indicates that the press followed the publisher's press strategy quite rigorously, suggesting an inverted gatekeeping situation with the publisher rather than the cultural desks performing as gatekeeper.

\section{Focus of the Coverage: The Controversial Production Process}

This power play is more complex, however, than these churnalism articles may suggest at first glance. This becomes apparent when looking more closely at the themes addressed in the coverage of the book. Numerous articles were, for example, about the book's (controversial) production process.

Especially copyright controversies and moral issues linked to the fourth book were in focus. They involved Stieg Larsson's girlfriend, Eva Gabrielsson, who opposed the decision to continue Larsson's work, and Stieg Larsson's family, who had the copyright to Larsson's books and decided to have more books produced. These are classic conflict stories with more celebre nuances. A headline in the tabloid Ekstra Bladet (August 27, 2015), for example, reads, "Offered 20 Million to Keep Quiet", reporting that Eva Gabrielsson had been offered money to stop publicly criticising the decision to produce more Millennium books. Similarly, the national newspaper, Politiken, published a first section, front-page story on August 26, 2015 under the headline "The Doomed Sequel", asking if the fourth book was "A literary resurrection or grave robbery?" as a teaser for an interview, also with Eva Gabrielsson, in the culture section. Terms such as "controversial", "grave robbery", "post hum violation", "fraud/fake" were used about the production of the book. Production-oriented stories also included more analytical angles about the ethics in continuing a deceased author's work. On January 25, 2014, Berlingske, for example, published the article: "Dead Authors Continue Writing", while the Christian-based newspaper Kristligt Dagblad published a similar story a few months later: "The characters of dead authors live on through other authors" (May 24, 2014). Both used the fourth Millennium book as a case for a broader argument.

Since many of these stories were published prior to the book's international launch, they indicate that churnalistic stories, preannouncing the coming of the book, were mixed with more analytical and reflective stories, addressing especially the book's commercial set-up and thus indicating a more critical framing.

\section{Lagercrantz: Author and/or Celebrity}

Author David Lagercrantz was also the centre of attention in the coverage, since a main question was whether he would be able to fill Larsson's shoes, again suggesting that the cultural journalists did not simply copy the framings of the publisher but also applied more reflective perspectives.

Numerous portraits framed Lagercrantz as a somewhat controversial character because he was the son of renowned Swedish literate, critic and cultural editor, Olof Lagercrantz, often associated with high culture and a publicist tradition. Lagercrantz's own CV was more modest, 
highlighting his experience as a sports reporter for the tabloid press and a ghostwriter or biographer. The coverage included headlines such as “The Man Who Only Wants to Dance with the Peculiar Ones" (Information, March 7, 2015), "The Shadow Writer Who Wanted to Be Seen" (Information, August 22, 2015) and "I Was Born to Do This. No One Can Do it Better"" (Jyllands-Posten, August 8, 2015). This focus on Lagercrantz is not surprising considering that cultural journalism has long taken an interest in the artists and personalities behind art works or artistic performances, resulting in blurred boundaries between celebrity journalism and cultural journalism (Marshall 2005; Van den Bulck, Paulussen, and Bels 2016). In the case in question, the debates about Lagercrantz and his skills as an author were constantly framed against his personal story. According to the Danish publisher, they had not planned this, however: "We did not encourage this focus on Lagercrantz and his father ... that was something the journalists themselves found interesting". Thus, one could argue that the publisher's controlled PR strategy of only distributing limited information about the book and making Lagercrantz difficult to access, implicitly staging him as extraordinary, left room for the press to set an agenda and frame him in a manner that did not necessarily comply with the publisher's scheme. This again indicates that the interplay of the culture industries and the cultural press may be more complex than suggested by the broad, critical claims about churnalism and cultural journalists' running the errands of the culture industries.

\section{Politiken's Meta-coverage}

This complexity becomes quite explicit in a critical meta-debate about the PR and media circus surrounding the book in the days prior to its publishing, instigated by the main cultural newspaper in Denmark, Politiken.

Politiken decided to boycott Norstedts' PR strategy in late August 2015. In the column "Hysterical Secrecy" (Politiken, August 23, 2015), the newspaper's literature editor, Jess Stein Pedersen, publicly criticised the publisher for taking too much control over the press and announced that the newspaper would not be part of this commercial orchestration anymore: "Neither the publisher, Lagercrantz nor all the curious readers are served by the course of events which have made it completely impossible to submit Lagercrantz to critical literature journalism". He thus alludes to Norstedts having violated the symbiotic interplay of the culture industries and the news media by means of secrecy and gatekeeping. Because of the numerous restrictions on interviews conducted with Lagercrantz at the press junket in June 2015, Politiken, for example, decided not to publish their interview with him. Instead, the newspaper used the occasion to problematise the interplay of the publishing industry and the press, i.e. to provide more critical self-reflective cultural journalism, but coverage all the same, for example, under the headline: "The Media Follow Tightened Demands from Publishers" (Politiken, August 27, 2015). Such meta-coverage, i.e. self-referential stories on the changing conditions of news production in view of various societal institutions' professionalised media management, is common in political communication, election coverage, and coverage of war and conflicts (e.g. Esser 2009). But the Millennium case exemplifies that it can also be a part of cultural journalism. Furthermore, the meta-coverage supports Politiken's brand as an agendasetting cultural newspaper. Following up on Politiken's statement, other Danish newspapers explicitly argued for why they had chosen to play by the publisher's rules. In a commentary 
article (August 27, 2015), cultural editor, Jesper Beinov, of the competing national newspaper, Berlingske, explained that although his newspaper also found the publisher's orchestration to be too much, they had decided to obey their demands considering the news value of the book and its importance to the newspaper's readers: "At Berlingske, we have made an ice-cold assessment: Is it in our readers' interest that we provide content and interview under these circumstances? Yes, it is. The interest in the Millennium series and its controversies is huge". But he admits to this being a slippery slope.

These multiple layers in the cultural intermediation processes, i.e. the publisher's professional push for churnalism, the extensive publicity-like copy in the newspapers and the meta-critical debates that this churnalism initiated, also influenced the critical reception of the book in the newspapers' reviews, as the following, final analytical section shows.

\section{Reviews: Moderately Positive Ratings but Critical Readings}

Despite the newspapers' meta-reflective discussions, the publisher still, to some extent, orchestrated the reviewers' critical debates about the book. Firstly, eight of the nine analysed newspapers reviewed the book, even though they did not have access to it prior to its release. This is not surprising since the newspapers are important co-creators of the hype and expectations surrounding the publishing of bestsellers (Thompson 2010, 249). In that sense, the reviews represented a (critical) culmination of these expectations - to the publisher, the news media and the public.

Secondly, six newspapers, including Politiken, reviewed the book on 28 August 2015 despite not gaining access to it until midnight between 26 and 27 August 2015, suggesting that the reviewers had very little time to read and review the book to make the deadline.

This confirms that release dates and temporal proximity represent a determining news value in cultural journalism (Golin and Cardoso 2009); it also exemplifies how far cultural editors are willing to go to review (almost) on the day of a release.

Thirdly, there is a paradoxical aspect to the reviews, however. While the newspapers typically rated the book three or four on a six-point scale, the headlines and evaluations provided in the reviews were more critical (see Figure 2). This indicates a contradiction between, on the one hand, the newspapers' ideas about the book's news value and their readers' literary preferences (and thus the service function served by the fairly positive ratings) and, on the other hand, the judgements of taste that the critics in fact wished to convey.

The original Larsson trilogy was the main point of reference in most reviews, as also signalled by their headlines. Plot, characters and thriller genre conventions were consequently compared to the previous books, and typically in critical terms. Several critics highlighted the slow plot, the Salander character having lost her touch, and that the book was a somewhat dull and excessively long thriller. Also Lagercrantz was constantly compared to Larsson. While most reviewers agreed that Lagercrantz was a better writer stylistically than Larsson and knew the genre, Larsson was persistently highlighted as more original, having more drive and being more authentic. Several reviews thus returned to the issues raised in the previewing articles on 
the book and their framing of Lagercrantz; that is, whether he could live up to Larsson, the moral and ethical issues connected to continuing the work of another author, and whether the book as literature could match all the attention created by the publisher (and the press). In this way, the publisher's PR strategy was also addressed in several reviews as part of a mainly critical framing of the commercial set-up and hype. The Danish publisher noticed this critical mix: "the reception in non-Scandinavian countries has been much more positive than in Scandinavia. This is most likely linked to the fact that in Scandinavia all the fuss [about the production process and the marketing] was intermingled with the reception and the book itself". One could perhaps even argue that the Swedish publisher's attempt to control the press sharpened the Danish reviewers' critical approach and influenced not only the news coverage of the book, but also the critical analysis of the book's literary qualities, i.e. influenced the cultural journalists' evaluations and classifications of the book.

\section{FIGURE 2}

August 28, 2015, Jyllands-Posten: "Blomkvist and Salander against digital supremacy" $\star \star \star \star ~$

* August 28, 2015, Berlingske (and Jyske Vestkysten): "New Millennium novel upholds its honour"

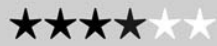

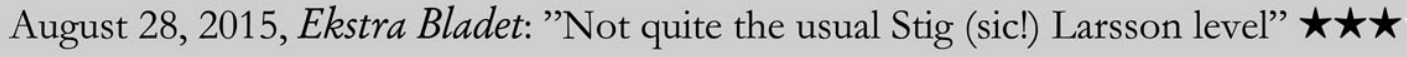

August 28, 2015, BT: "New Salander book without emotions" $\star \star \star ~$

August 28, 2015, Politiken: "An endless marathon" $\star \star \star ~$

August 29, 2015, Information: "Salander revived" (no rating)

Review headlines and ratings. *The reviews from Berlingske (national) and Jyske Vestkysten (regional) were identical

\section{Conclusion}

When trying to grasp a phenomenon such as churnalism, it is important, as argued in this article, to look into the particular nature of specific journalistic beats rather than simply transferring or applying the broader ideologies of journalism. This article has engaged with churnalism within the specialised beat of cultural journalism, since information subsidies seem to play a pronounced role in news media's previewing, reporting and reviewing of art and culture. This circumstance has led to cultural journalists repeatedly being accused in the scholarly literature and public debate of disobeying the norms of journalism. Rather than repeating this critique, this article has turned to theories about cultural (inter)mediation in order to try to explain why churnalism is so pronounced in cultural journalism and, at times, even seems to comply with the professional norms and practices of the beat. This theoretical framework has pointed to cultural journalists performing complex and intertwined roles as cultural gatekeepers, connectors, marketers and valorisers, roles that are quite different from, for example, the norms and roles of autonomous, objective disseminators, watchdogs or 
observers, typically associated with Western journalism.

The article has also tried to nuance these theoretical arguments by means of an analysis of how these mediator logics take shape in empirical practice, and how they facilitate churnalism. A case study of the interplay of the publishing industry and the Danish press when the fourth Millennium book was publicised in 2015, firstly, confirmed the control that culture industries try to exercise over media coverage and that churnalism quite easily finds its way into the cultural pages, suggesting an inverted gatekeeping situation. Secondly, it exemplifies the intertwined interests and logics of the cultural press and the culture industries: the publisher needed the press to hype the book, but the book also represented a newsworthy story, being a huge cultural event of great interest to a broad range of newspaper readers. Thus, the case exemplifies the symbiotic relations between cultural journalists and their sources in the culture industries, and how both parties played an important role in promoting the book. Thirdly, the case suggests that during the course of events these interests do not necessarily follow the same path. The publisher's controlled PR set-up gave the press an occasion to address and comment on the more ethical and normative questions linked to an author continuing the work of another artist and not least on the conditions for the cultural press itself when interacting with an increasingly professionalised culture industry. Thus, the case exemplifies how the cultural press may, at times, try to resist pressures for churnalism by applying a meta-reflective and analytical approach to the commercial strategies of the culture industries. While this is perhaps done less to perform the traditional autonomous watchdog or adversary role of journalism, it nonetheless positions the press at a distance of its sources and adds a reflective layer to the coverage and its churnalism. This echoes the more general trend of self-referentiality (e.g. Nöth 2007) and metacoverage (e.g. Esser 2009) in journalism, pointing to the increased public attention to the professional performances of the news institution. Also the reviews' literary-critical debates about the qualities of the Millennium book were framed in light of the book's commercial setup, pointing to the complex intertwinement of cultural journalists' roles as gatekeepers, connectors, marketers and valorisers.

While the Danish context may not be representative for cultural journalism more broadly, the findings exemplify how the Nordic media welfare model's subsidy regulations, public service ideology, arms' length principles, etc. (Ahva et al. 2016; Syvertsen et al. 2014) implicitly support the complex cultural (inter)mediary logics of cultural journalism. On the one hand, they ensure attention to and dissemination of culture, thus encouraging cultural journalists to mediate between cultural producers and cultural consumers; on the other hand, they ensure that cultural journalists can also apply critical and analytical perspectives in these mediation processes. Lastly, while the Millennium case may be extreme compared to most cultural products in view of the controversial nature of the book's production and its longitudinal promotion, it is a showcase for making the argument that, even though churnalism may be pronounced in cultural journalism, and especially in relation to large-scale cultural productions, this does not necessarily mean that the cultural press is always naively, uncritically or unreflectively running the errands of the cultural industries. 


\section{DISCLOSURE STATEMENT}

No potential conflict of interest was reported by the authors.

\section{FUNDING}

This work was supported by the Danish Research Council for Independent Research [grant number DFF-4180-00082] and Arts Council Norway [grant number 15/19684-2].

\section{NOTES}

1. Though the literature often quotes Forde $(2003,113)$ for introducing this term, Forde in fact references English (1979) for having introduced it.

2. The use of various terms in the international literature complicates the full picture of the research field. In the Anglo-Saxon tradition "arts journalism" is a common term (e.g. Szántó, Levy, and Tyndall 2004), but Nordic scholarship uses "cultural journalism".

3. Since Bourdieu introduced the term, the literature has provided numerous definitions of cultural intermediaries and used it about a variety of professional groups beyond those working in the news industry (e.g. Maguire and Matthews 2014).

4. Strahan (2011) shows than 8 in 10 cultural articles in Australian newspapers arise from cultural events or releases of new cultural products or from interviews with artists or cultural producers. Also 8 in 10 cultural articles in Danish print/online newspapers represent some sort of churnalism, based on news agency information, other news media's stories, a press release, press junkets or reports pushed by news sources (Kristensen 2016).

5. These data were collected in Spring 2016 as part of a comparative Nordic study involving Denmark, Finland, Norway and Sweden. This article only reports on selected parts of the Danish coverage. The tabloids are: BT (centre-right, 144,000 daily readers) and Ekstra Bladet (centre-left, 149,000 daily readers). The national newspapers, considered the main news- papers in Denmark due to circulation, agenda-setting role and different political leadings, are: Politiken (centre-left with a distinct cultural profile, 325,000 daily readers), Berlingske (conservative, 195,000 daily readers) and Jyllands-Posten (liberal, 235,000 daily readers). The two niche newspapers are Information (leftwing, 94,000 daily readers) and Kristligt Dagblad (Christian-based, 118,000 daily readers). The two regional newspapers are: Jyske Vestkysten (representing the Jutland region, 134,000 daily readers) and Fyens Stiftstidende (representing the Fyn region, 95,000 daily readers). See Q4 2015 and Q1 2016 figures from Gallup: http://tns-gallup.dk/work/media/laesertal/Læsertal\%204k\%202015\% 20\%201k\%202016.pdf (accessed December 19, 2016).

6. The omitted articles were typically about Lagercrantz's biography of Swedish football legend Zlatan Ibrahimovic from 2011.

7. This was also a distinctively different strategy compared to similar large-scale publications such as Dan Brown's The Da Vinci Code. Thompson (2010, 249), for example, points out that 10,000 reading copies were distributed to initiate press coverage and word-of-mouth prior to this book's publishing. 


\section{REFERENCES}

Ahva, Laura, Arjen van Dalen, Jan Fredrik Hovden, Guðbjörg Hildur Kolbeins, Monica Löfgren Nilsson, Morten Skovsgaard, and Jari Väliverronen. 2016. “A Welfare State of Mind.” Journalism Studies 18: 595-513. doi:10.1080/1461670X.2016.1249005.

Baumann, Shyon. 2001. "Intellectualization and art World Development: Film in the United States." American Sociological Review 66 (3): 404-426.

Blank, Grant. 2007. Ratings, Critics and Society. Lanham: Rowman \& Littlefield Publishers. Bourdieu, Pierre. 1984. Distinction: A Social Critique of the Judgement of Taste. London: Routledge.

Danish Agency for Culture. 2016. Bogen og litteraturens vilkår 2016 [The Conditions of Books and Literature 2016]. Copenhagen: Kulturstyrelsen.

Davis, Aeron. 2013. Promotional Cultures. Cambridge: Polity.

Deuze, Mark. 2005. "What is Journalism? Professional Identity and Ideology of Journalism Reconsidered." Journalism 6 (4): 442-464.

Dubied, Annik, and Thomas Hanitzsch. 2014. "Studying Celebrity News.” Journalism 15 (2): 137-143.

English, John W. 1979. Criticising the Critics. New York, NY: Hastings House.

Esser, Frank. 2009. "Metacoverage of Mediated Wars: How the Press Framed the Role of the News Media and of Military News Management in the Iraq Wars of 1991 and 2003." American Behavioral Scientist 52 (5): 709-734.

Forde, Eamonn. 2003. “Journalists with a Difference: Producing Music Journalism.” In Media Organisations and Production, edited by Simon Cottle, 113-130. London: Sage.

From, Unni. 2010. "The Reading of Cultural and Lifestyle Journalism.” Northern Lights: Film and Media Studies Yearbook 8: 157-175.

Gandy, Oscar. 1982. Beyond Agenda-Setting: Information Subsidies and Public Policy. New York: Ablex Publishing Company.

Golin, Cida, and Everton Cardoso. 2009. "Cultural Journalism in Brazil: Academic Research, Visibility, Mediation and News Values.”Journalism 10 (1): 69-89.

Gripsrud, Jostein. 2009. "The Cultural Dimension of Democracy." In Media, Democracy and European Culture, edited by Ib Bondebjerg and Peter Madsen, 197-214. Bristol: Intellect Books.

Hallin, Daniel C., and Paolo Mancini. 2004. Comparing Media Systems. Cambridge: Cambridge University Press.

Hanitzsch, Thomas. 2007. "Deconstructing Journalism Culture: Toward a Universal Theory." Communication Theory 17 (4): 367-385. 
Hanusch, Folker. 2012. "Broadening the Focus. The Case for Lifestyle Journalism as a Field of Scholarly Inquiry." Journalism Practice 6 (1): 2-11.

Harcoup, Tony. 2014. A Dictionary of Journalism. Oxford: Oxford University Press.

Harries, Gemma, and Karin Wahl-Jorgensen. 2007. “The Culture of Arts Journalists.” Journalism 8 (6): 619-639.

Helgason, Jon, Sara Kärrholm, and Ann Steiner, eds. 2014. Hype. Bestsellers and Literary Culture. Lund: Nordic Academic Press.

Hellman, Heikki, and Maarit Jaakkola. 2012. "From Aesthetes to Reporters: The Paradigm Shift in Arts Journalism in Finland.” Journalism 13 (6): 783-801.

Hjarvard, Stig. 2013. The Mediatization of Culture and Society. London: Routledge.

Hjarvard, Stig. 2016. “Danskernes smag for litteratur” [Danes' Taste for Literature]. Passage 76: 145167.

Hovden, Jan-Fredrik, and Karl Atle Knapskog. 2015. "Doubly Dominated. Cultural Journalists in the Fields of Journalism and Culture.” Journalism Practice 9 (6): 791-810.

Jaakkola, Maarit. 2015. The Contested Autonomy of Arts and Journalism: Change and Continuity of the Dual Professionalism of Cultural Journalism. Tampere: Tampere University Press.

Jackson, Daniel, and Kevin Moloney. 2016. “Inside Churnalism.” Journalism Studies 17 (6): 763 780 .

Janssen, Susanne, Giselinde Kuipers and Marc Verboord. 2008. "Cultural Globalization and Arts Journalism: The International Orientation of Arts and Culture Coverage in Dutch, French, German, and U.S. Newspapers, 1955 to 2005." American Sociological Review 73 (5): 719-740.

Janssen, Susanne, and Marc Verboord. 2015. “Cultural Mediators and Gatekeepers.” In International Encyclopedia of the Social \& Behavioral Sciences, edited by James D. Wright, 440-446. 2nd ed. Vol. 5. Oxford: Elsevier.

Klein, Bethany. 2005. "Dancing About Architecture: Popular Music Criticism and the Negotiation of Authority." Popular Communication 3 (1): 1-20.

Knapskog, Karl Atle, and Leif Ove Larsen, eds. 2008. Kulturjournalistikk. Pressen og den kulturelle offentlighed [Cultural Journalism. The Press and the Cultural Public Sphere]. Oslo: Scandinavian Academic Press.

Koreman, Rian. 2014. "Legitimating Local Music: Volksmuziek, Hip-Hop/Rap and Dance Music in Dutch Elite Newspapers.” Cultural Sociology 8 (4): 501-519.

Kristensen, Nete Nørgaard. 2003. “Journalister og kilder - sliger i valsen?” [Journalists and News Sources - Is There a Glitch?]. PhD-dissertation. University of Copenhagen.

Kristensen, Nete Nørgaard. 2010. “The Historical Transformation of Cultural Journalism.” Northern 
Lights: Film and Media Studies Yearbook 8(1): 69-92.

Kristensen, Nete Nørgaard. 2016. "Kulturjournalistikkens dagsordener og dagsordensættere på tværs af platforme" [The Agendas and Agenda-Setters of Cultural Journalism Across Plat- forms]. In Den Fælles Dagsorden og Alle De Andre [The Mutual Agenda and All the Others], edited by Ida Willig and Mark Blach-Ørsten, 243-261. Frederiksberg: Samfundslitteratur.

Kristensen, Nete Nørgaard, and Unni From. 2012. "Lifestyle Journalism: Blurring Boundaries.” Journalism Practice 6 (1): 26-41.

Kristensen, Nete Nørgaard, and Unni From. 2015a. "Cultural Journalism and Cultural Critique in a Changing Media Landscape.” Journalism Practice 9 (6): 760-772.

Kristensen, Nete Nørgaard, and Unni From. 2015b. "Publicity, News Content, and Cultural Debate: The Changing Coverage of Blockbuster Movies in Cultural Journalism." Communication, Culture \& Critique 8: 484-501.

Littlewood, Thomas B. 1998. Calling Elections: The History of Horse-Race Journalism. NotreDame: University of Notre Dame Press.

Maguire, Jennifer Smith, and Julian Matthews, eds. 2014. The Cultural Intermediaries Reader. London: Sage.

Marshall, P. David. 2005. "Intimately Intertwined in the Most Public way - Celebrity and Journalism.” In Journalism: Critical Issues, edited by Stuart Allan, 19-29. Berkshire: Open University Press.

Neveu, Erik. 2002. “Four Generations of Political Journalism.” In Political Journalism; new Challenges, new Practices", edited by Raymond Kuhn and Erik Neveu, 24-44. London: Routledge.

Newman, Nic, David Levy, and Rasmus K. Nielsen. 2015. Reuters Institute Digital News Report 2015. Oxford: Reuters Institute for the Study of Journalism.

Nöth, Winfried. 2007. "Self-Reference in the Media: The Semiotic Framework.” In Self-Reference in the Media, edited by Winfried Nöth and Nina Bishara, 3-30. Hague: Holland Mouton de Gruyter.

Olsen, Tryve. 2014. Kritisk kulturjournalistikk [Critical Cultural Journalism]. Oslo: Cappelem Damm. Rixon, Paul. 2011. TV Critics and Popular Culture: A History of British Television Criticism. London: I.B. Tauris.

Sarrimo, Cristine. 2016. “The Press Crisis and its Impact on Swedish Arts Journalism.” Journalism online first. doi:10.1177/1464884915625629.

Schmutz, Vaughn, Alex van Venrooij, Susanne Janssen, and Marc Verboord. 2010. "Change and Continuity in Newspaper Coverage of Popular Music Since 1955: Evidence From the United States, France, Germany, and the Netherlands.” Popular Music and Society 33 (4): 501-515.

Schreier, Margit. 2012. Qualitative Content Analysis in Practice. London: Sage.

Scott, Robert D. 1999. "Bridging the Cultural Gap: How Arts Journalists Decide What Gets Onto the 
Arts and Entertainment Pages.” Critical Quarterly 41 (1): 46-55.

Shoemaker, Pamela, Tim Vos, and Steven D. Reese. 2009. "Journalists as Gatekeepers." In The Handbook of Journalism Studies, edited by Karin Wahl-Jorgensen and Thomas Hanitzsch, 73-87. New York, NY: Routledge.

Shrum, Wesley. 1991. "Critics and Publics: Cultural Mediation in Highbrow and Popular Performing Arts.” American Journal of Sociology 97 (2): 347-375.

Strahan, Lucinda. 2011. "Sources of Arts Journalism. Who's Writing the Arts Pages?” In Journalists, Sources, and Credibility, edited by Bob Franklin and Matt Carlson, 127-138. London: Routledge.

Syvertsen, Trine, Gunn Enli, Ole J. Mjøs, and Hallvard Moe. 2014. The Media Welfare State: Nordic Media in the Digital Area. Ann Arbor, MI: University of Michigan Press.

Szántó, András, Daniel S. Levy, and Andrew Tyndall, eds. 2004. Reporting the Arts II. Columbia University: National Arts Journalism Program.

Thompson, Kristin. 2007. The Frodo Franchise: The Lord of the Rings and Modern Hollywood. Oakland: University of California Press.

Thompson, John B. 2010. Merchants of Culture. The Publishing Business in the Twenty-First Century. Cambridge: Polity.

Turner, Barry, and Richard Orange. 2013. Specialist Journalism. Oxon: Routledge.

Van den Bulck, Hilde, Steve Paulussen, and Annebeth Bels. 2016. "Celebrity News as Hybrid Journalism: An Assessment of Celebrity Coverage in Flemish Newspapers and Magazines.” Journalism. online first. doi:10.1177/1464884916657523.

Verboord, Marc. 2010. "The Legitimacy of Book Critics in the Age of the Internet and Omnivorousness: Expert Critics, Internet Critics and Peer Critics in Flanders and the Netherlands." European Sociological Review 26 (6): 623-637.

Verboord, Marc, and Susanne Janssen. 2015. "Arts Journalism and Its Packaging in France, Germany, The Netherlands and the United States, 1955-2005.” Journalism Practice 9 (6): 829-852.

Weaver, David, and Lars Willnat, eds. 2012. The Global Journalist in the 21st Century. New York, NY: Routledge.

Nete Nørgaard Kristensen, Department of Media, Communication and Cognition, Section for Film, Media and Communication, University of Copenhagen, Denmark. E-mail: netenk@hum.ku.dk. Web: http://mcc.ku.dk/staff/?pure=en/persons/171964 